\title{
TRIAL PRODUCTION OF SURGICAL GLOVES FROM IRRADIATED NATURAL RUBBER LATEX ON FACTORY SCALE
}

\author{
Marga Utama ${ }^{1}$, Herwinarni ${ }^{1}$, Made Sumarti ${ }^{1}$, Siswanto $^{2}$, Suharyanto ${ }^{2}$, \\ Sunardi Ruslim ${ }^{3}$. \\ ${ }^{1}$ Center for Research and Development of Isotopes and Radiation Technology, \\ National Nuclear Energy Agency, Jl. Cinere Ps. Jumat Jakarta. \\ ${ }^{2}$ Indonesian Biotechnology Research Institute for Estate Crops, Jl. Taman Kecana 1 Bogor. \\ ${ }_{3}^{3}$ PT. Laxindo Utama, Serang, Banten.
}

\begin{abstract}
TRIAL PRODUCTION OF SURGICAL GLOVES FROM IRRADIATED NATURAL RUBBER LATEX ON FACTORY SCALE. Trial production of surgical gloves from irradiated natural rubber latex at the PT. Laxindo Utama Serang Banten glove factory has been carried out. The variation of heating temperature and leaching time during processing were evaluated. The physical and mechanical properties and the protein allergen respond of surgical gloves using ELISA method were measured. The results showed that the physical and mechanical of surgical gloves such as tensile strength, modulus, and elongation at break are found to meet the requirements of the ISO or SNI standard for surgical gloves. While the allergic response through clinical tested latex-sensitive protein allergen known as ELISA test is found to be negative.
\end{abstract}

Key words : Surgical gloves, negative test latex-sensitive allergic, irradiation technique.

\section{INTRODUCTION}

Current issues to latex dipped goods manufactures are : biodegradability, the volatile nitrosamines, and nitrosable amines, and some latex protein allergy in some of the latex products. Recent studies shown that latex product such as gloves and balloons are biodegradable [1-2].

It has been well known that $\mathrm{N}$-nitrosamines are found widely in the environment, in foodstuffs, beverages, beer, rubber products, etc. Nitrosamines are formed through the nitrosation of secondary amino compound by such chemicals as nitrites (presents in the food preservatives and in saliva), nitrates (from fertilizer), or atmospheric nitrogen dioxide. While it has been shown as well as that nitrosamines is a potent carcinogen in animal test producing liver, kidney, and lung cancer [3-5].

Proteins in fresh natural rubber latex (NRL) are distributed in the three major fraction; the rubber phase (27\%), the B serum (25\%), and the C-serum $(48 \%)$. The major proportion of water soluble protein in fresh latex is derived from the B-and C-sera. About $1 \%$ of the population is believed to be allergic to NRL. Over 1000 allergic and anaphylactic reaction and 15 anaphylactic deaths were related to latex product such as gloves, catheter, condom, etc [6-8]. 
There are two main type of allergy associated with NRL products; first is delayed cell-mediated hypersensitivity Type IV allergy and second is an IgE mediated immediate hypersensitivity Type I allergy.

Type IV allergy has been known for decades and is attributed to the presence of chemical residue in the rubber products. These compounds include thiuram, mercaptobenzthiazole, dithiocarbamates, diphenylguanidine, and thiourea. The Type I hypersensitivity is due to residual water soluble proteins present in some rubber products made from NRL [9-10].

Alternative way for producing free nitrosamine and nitrosable have been developed such as, pre-vulcanized NRL in the form of peroxide prevulcanized latex and pre- radiation vulcanized latex. The physical properties of them are observed and the films are essentially free of soluble protein [11-14].

The Indonesian Nuclear Energy Agency has established a commercial pilot facility for producing radiation vulcanized of natural rubber latex (RVNRL) or irradiated natural rubber latex (INRL) by gamma irradiation as a energy source for vulcanization since 1983 [15-18] This INRL has been used for condom production and examination gloves in factory scale [19-20]. The quality of this production was INRL Type II (Table 1). The dipping machine for production of examination gloves was an automatic dipping made in USA, while in this study the surgical gloves machine was used the semi automatic dipping machine made in Indonesia with the flow diagram shows in Figure 1, with the purpose is to prove that this machine can produce the surgical from INRL.

This paper describes a factory trial production of surgical gloves from INRL. The heating temperature and leaching time during processing were evaluated. The hypothesis of this study is to prove that gloves from INRL is safe for user.

\section{MATERIAL AND METHOD}

Material. The High ammonia (HA) latex and INRL produced by PTPVIII and P3TIR-BATAN on January 2003 and April 2004 were used as raw materials. The properties of the latex and its film are shown in Table 1. The chemical for analysis of water soluble protein, and allergic response through ELISA method, were acrylamide, glycerol, methanol, acetic acid etc. The chemical for sulfur vulcanization such as merchaptobenzothiazole, dithiocarbamat, sulfur, $\mathrm{ZnO}$ etc. 
Table 1. The HA latex and INRL was used for the trial production of surgical gloves.

\begin{tabular}{|c|c|c|c|c|}
\hline \multirow[t]{2}{*}{ No. } & \multirow[t]{2}{*}{ Properties } & \multirow{2}{*}{$\begin{array}{c}\text { High } \\
\text { ammonia } \\
\text { (HA) latex }\end{array}$} & \multicolumn{2}{|c|}{$\begin{array}{l}\text { Irradiated natural rubber } \\
\text { latex (INRL) }\end{array}$} \\
\hline & & & Type I & Type II \\
\hline \multicolumn{5}{|c|}{ Latex } \\
\hline 01 & Total solid content (TSC), $\%$. & 60,97 & 62,32 & 56,12 \\
\hline 02 & Dry rubber content (DRC), $\%$. & 60,00 & 60,98 & 55,00 \\
\hline 03 & TSC-DRC & 0,97 & 1,34 & 1,12 \\
\hline 04 & Ammonia content (NH3),\% latex. & 0,71 & 0,77 & 0,78 \\
\hline 05 & Volatile Fatty acid (VFA) number. & 0,0417 & 0,0109 & 0,0400 \\
\hline 06 & KOH number & 0,61 & 0,60 & 0,61 \\
\hline 07 & $\mathrm{pH}$ & 9,99 & 10,04 & 10,20 \\
\hline 08 & Mg content, \%. & 0,0035 & 0,0062 & 0,0033 \\
\hline 09 & $\begin{array}{l}\text { Mechanical stability time (MST) number, } \\
\text { sec. }\end{array}$ & 1.500 & 1800 & 1800 \\
\hline 10 & Viscosity, cP. & 80 & 350 & 75 \\
\hline \multicolumn{5}{|l|}{ Film } \\
\hline 11 & Modulus $600 \%, \mathrm{MPa}$. & 0,2 & 1,7 & 1,7 \\
\hline 12 & Tensile strength, MPa. & 2,1 & 22 & 23 \\
\hline 13 & Elongation at break, $\%$. & 1100 & 1000 & 1000 \\
\hline
\end{tabular}

Type I INRL : field latex, irradiated, concentrated, then added with sodium laurate, Type II INRL: concentrated latex, irradiated

Apparatus. Surgical gloves line factory with gloves former made from porcelain. The trial production was conducted at PT. Laxindo Utama Serang Banten. The apparatus for measurement the physical properties of gloves, soluble protein and allergic response were prepared by biotechnology laboratory UPBP Bogor, and PATIR-BATAN Jakarta.

\section{PRODUCTION OF INRL}

The procedure for production of INRL Type I in pilot scale are as follow : Around 8 tones of Field NRL with dry rubber content $28 \%$ and $2 \%$ of $\mathrm{NH}_{4} \mathrm{OH}$ were added by $3 \mathrm{phr}$ (part hundred of rubber) emulsion of normal butyl acrylate then irradiated by gamma rays at $25 \mathrm{kGy}$. During irradiation the mixture were mixed continuous. The irradiated field NRL were then concentrated by means of centrifugation method in factory scale. The specification of INRL Tipe I was shown on Table 1.

The procedure for production of INRL type II in pilot scale are as follow: Around 1,5 tones of centrifuged NRL with dry rubber content 55\%, were added by $3 \mathrm{phr}$ (part hundred of rubber) emulsion of normal butyl acrylate then irradiated by gamma rays at $25 \mathrm{kGy}$. During irradiation the mixture were mixed continuous. The specification of INRL tipe II was shown on Table 1. 


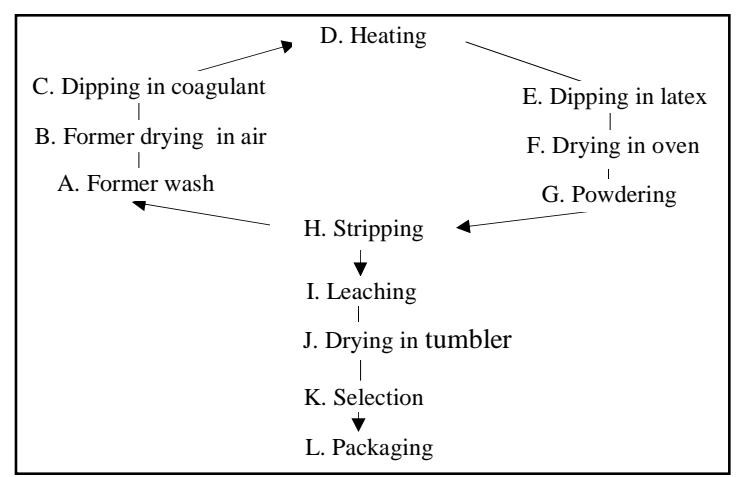

Figure 1. Flow diagram of surgical gloves production in factory scale.

\section{PRODUCTION OF SURGICAL GLOVES}

Figure 1 shows a flow diagram of surgical gloves line in factory scale. The coagulant bath contains calcium nitrate with concentration around 15\%, the latex dipping contains INRL compound with the BHT antioxidant. The procedure is as follows : The gloves former was cleaned (A), then dried (B), after drying dipped into coagulant (C), Heating in air for several minutes (D) , then dipped into latex compound (E), dried in oven at $130^{\circ} \mathrm{C}$ during 3 , $5,7,10$, or 15 minutes $(F)$, then powdering the gloves $(\mathrm{G})$, stripped the gloves $(\mathrm{H})$, then the gloves were leached (I) with water, $1 \%$ of ammonia, or $0,1 \%$ cationic soap. After leaching the gloves were dried in tumbler $(\mathrm{J})$, and after selection $(\mathrm{K})$ the quality the good gloves were packaged $(\mathrm{L})$.

Table 2. Formulation of INRL and HA latex for producing surgical gloves on factory scale.

\begin{tabular}{|c|c|c|c|c|c|c|}
\hline \multirow[t]{2}{*}{ No. } & \multirow[t]{2}{*}{ Chemical formulation } & \multicolumn{5}{|c|}{ Formulation number } \\
\hline & & $\mathrm{A}$ & $\mathrm{B}$ & $\mathrm{C}$ & $\mathrm{D}$ & $\mathrm{E}$ \\
\hline 1 & 60\% HA. Latex, phr. & - & - & - & - & 100 \\
\hline 2 & 60\% INRL Type I, phr. & - & 100 & 100 & 100 & - \\
\hline 3 & 55\% INRL Type II, phr. & 100 & - & - & - & - \\
\hline 4 & $10 \% \mathrm{KOH}$,phr. & - & - & - & - & 0.3 \\
\hline 5 & $25 \%$ K. laurate, phr. & - & - & - & - & 0.3 \\
\hline 6 & $50 \%$ sulfur, phr & - & - & - & - & 0,7 \\
\hline 7 & $50 \% \mathrm{ZnO}$, phr. & - & - & - & - & 0,5 \\
\hline 8 & $50 \%$ BHT anti oxidant, phr. & 0,5 & 0,5 & 0,5 & 0,5 & 1.0 \\
\hline 9 & $50 \%$ Vulcasit LDA, phr. & - & - & - & - & 0,3 \\
\hline 10 & $50 \%$ Vulcanox SP, phr. & - & - & - & - & 0,2 \\
\hline 11 & 1\% Polyvinyl Alcohol (PVA), phr. & - & - & 0,01 & - & - \\
\hline 12 & $1 \%$ Carboxy methyl cellulose (CMC), phr. & - & - & - & 0,01 & - \\
\hline
\end{tabular}


Evaluation of latex and its surgical gloves. Measurement the properties of latex and surgical gloves such as dry rubber content, total solid content, viscosity, tensile strength, modulus, etc. was carried out according to ASTM [21-22].

Determines of protein allergic response. Measurement of water soluble protein and ELISA protein allergic method was carried out according to references $[23,24]$.

\section{RESULTS AND DISCUSSION}

Seven factors will be discussed in this paper : compounding of INRL, coagulant mixture, drying in oven, leaching process, drying in tumbler, effect of allergic response of difference type of INRL, and quality of surgical gloves.

Compounding of INRL. The INRL compound for trial production of surgical gloves in factory scale was prepared using formulation A to $\mathrm{E}$ (Table 2). The compound used in the trial was diluted to 50\% of TSC (total solid content) before being maturated. The formulation A to D was maturated for one night (17 hours), but the formulation $\mathrm{E}$ was maturated for three days, because the maturation step is necessary as according to laboratory experiment, it improves the tensile strength of film (Figure 2). It was indicated that the optimum maturation of HA latex much longer than the INRL chemical compound and the time of maturation. Because the INRL is pre-vulcanized latex, which have a cross-link among the poly-isoprene rubber, but the HA latex does not have a cross-link, so it need more energy for making a pre-vulcanized latex, hence it need more longer time. NG K.P.E. YIP and K.L,MOK[25] reported that the optimum maturation time of H.A from DPNR latex for producing gloves is 5 days.

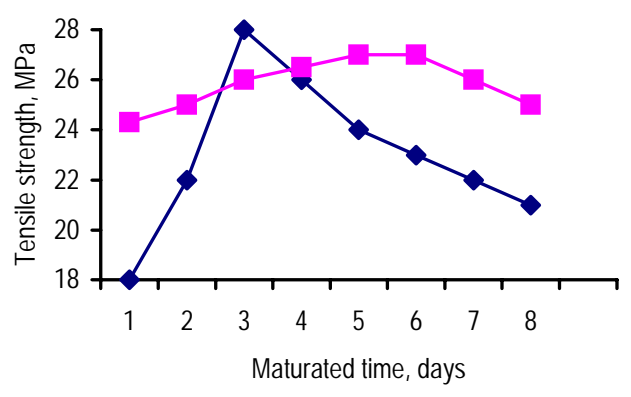

- HA latex compound - INRL compound

Figure 2. Effect of maturation time on tensile strength (curing temperature of $\mathrm{INRL}=100^{\circ} \mathrm{C} / 15$ minutes, HA. Latex compound $=130{ }^{\circ} \mathrm{C} / 15$ minutes). 


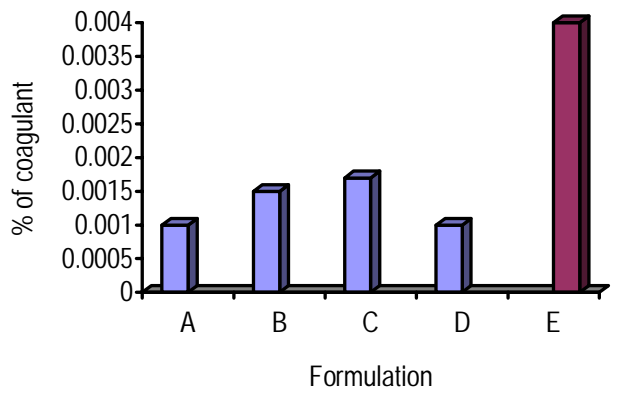

$\square$ INRL compound $\square$ HA latex compound

Figure 3. Coagulum content of INRL and HA latex compound (formulation A-E is prepared on Table 2).

For preventing pre-coagulation, stirring of the compound is done slowly with the mixer speed not more then $40 \mathrm{rpm}$. Figure 3 shows that the coagulum contents of INRL compound were lower than that HA latex compound, because formulation of INRL contained less chemicals than that of HA latex (Table 2). It indicates that the stability of INRL compound is higher than HA latex compound.

Coagulant mixture. The effect of varying concentration of calcium nitrate on the thickness of INRL and HA latex compound film is shown on Figure 4. From this figure shows that by increasing the coagulant concentration from 1 to $14 \%$ the thickness of film increases, and the optimum concentration of calcium nitrate is around 9-10\%. It means that during immersion the glove former which has been coated by the $\mathrm{Ca}\left(\mathrm{NO}_{3}\right)_{2}$ on the surface of INRL occur, because $\mathrm{Ca}\left(\mathrm{NO}_{3}\right)_{2}$ can coagulate among the rubber particle. By increasing the concentration of $\mathrm{Ca}\left(\mathrm{NO}_{3}\right)_{2}$, the thickness rubber film increase. The standard thickness of surgical gloves film is around 0,1 to $0,2 \mathrm{~mm}$. For obtaining this thickness the concentration of $\mathrm{Ca}\left(\mathrm{NO}_{3}\right)_{2}$ is around $9-10 \%$, so the optimum concentration of $\mathrm{Ca}\left(\mathrm{NO}_{3}\right)_{2}$ is $9-10 \%$.

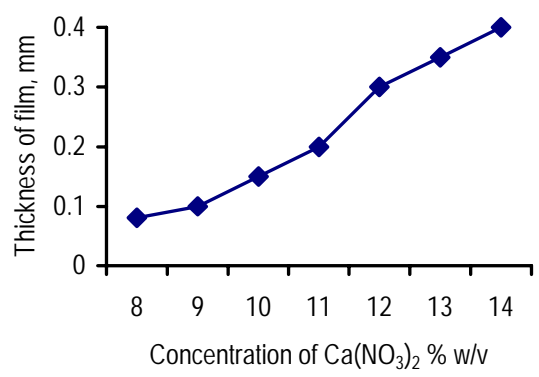

Figure 4. Effect of $\mathrm{Ca}\left(\mathrm{NO}_{3}\right)_{2}$ concentration on the thickness of gloves film. 


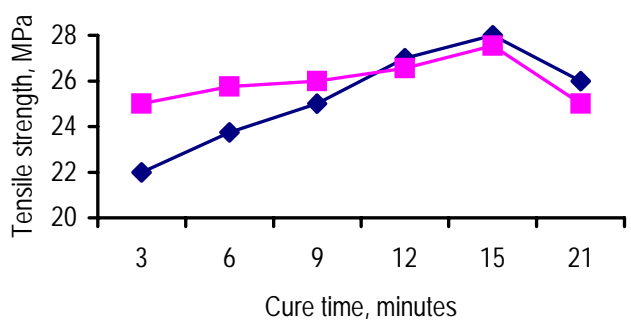

- Cure temperature of HAL S.G 130 oC

- Cure temperature of INRL S.G 100 oC

Figure 5. Effect of cure time on the tensile strength of gloves film.

Dipping process. Production of surgical gloves was carried out in typical line as shown on Figure 1, with the size of porcelain former was 77,5. INRL compound in the maturation tank was agitated for several minutes, filtered and placed in the dipping tank. It was continuously stirred during dipping process.

Several factors should be observed during dipping process such as temperature of INRL compound in latex dip tank is around $28-30{ }^{\circ} \mathrm{C}$, be sure that the coagulant coated former is dried, after dipping the foam on the surface of INRL compound should be removed, and be sure that no pine hole on surgical gloves occur. If the surgical gloves have a pine hole, it mean that there is a volatile matter in the INRL compound, then after heating at more than $28-30^{\circ} \mathrm{C}$ it become gas, and its consequence there is an air in the INRL compound.

Drying in oven. It has been reported that dry rubber and dry rubber products have extremely low extractable protein level, if they use de-protein natural rubber (DPNR), if they leached with water in a good condition of leaching. When tested clinically, this material demonstrated very low or negligible allergenic. Therefore, it may be concluded that these products are relatively little or not affected by the protein allergy problem encountered by some latex dipped products [25].

In this study the purpose of drying surgical gloves from INRL is only to remove the water content, not vulcanization, because INRL is a prevulcanized latex which has been vulcanized by gamma irradiation. Figure 5 shows that optimum curing temperature and time of gloves from INRL is $100^{\circ} \mathrm{C} / 15$ minutes, while curing temperature ant time of surgical gloves from of HA latex compound is $130^{\circ} \mathrm{C}$ in 15 minutes. It means that heating temperature needed for producing gloves from INRL less then HA latex.

Drying in tumbler. The process was extended to include tumbling for removal of excess powder and to even out powder content in gloves.

Leaching. Leaching is the process of removal of hydrophilic materials from latex dipped products by washing them in water or other solution. It is 
an essential process in the production of latex dipped products. The removal of excess calcium nitrate, non rubber constituent such as protein, carbohydrate, lipid, etc can improve physical properties of surgical gloves [26].

There are basically two methods of leaching viz; wet gel film leaching and dry-film leaching. Wet gel leaching. Wet gel leaching is usually carried out on-line, but dry-film leaching consist of the washing of dried surgical gloves removal from the former.

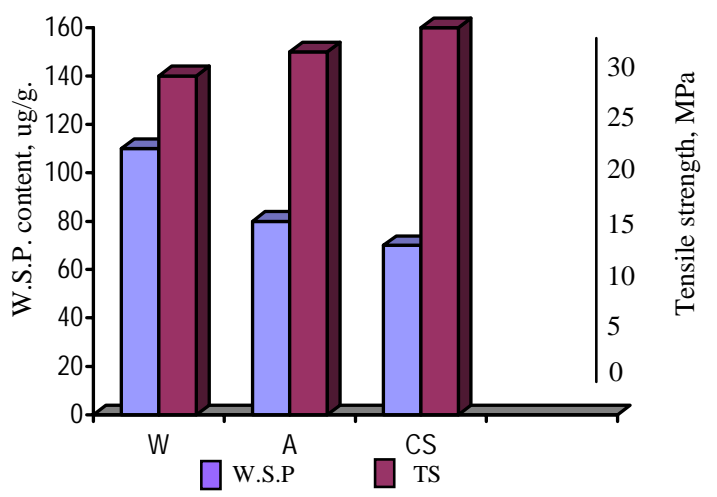

Figure 6. Effect of leaching in water (W), $1 \%$ Ammonia (A), and 0,01\% cationic soap (CS) on water soluble protein (WSP) content and tensile strength.

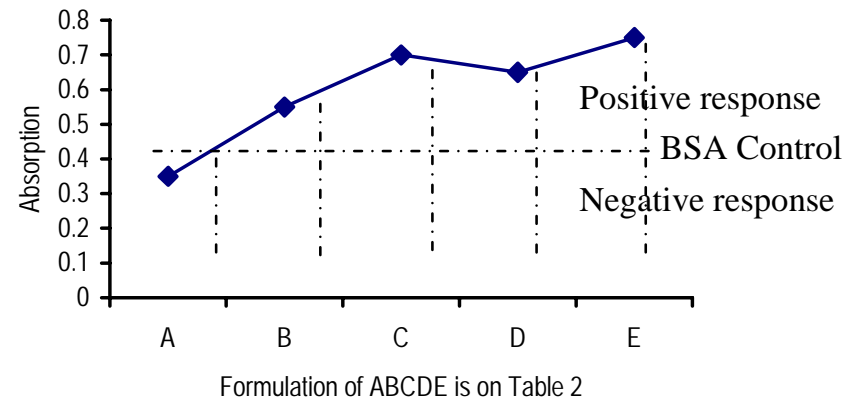

Figure 7. Effect of compounding of surgical gloves on the protein allergenic response.

In this study the leaching of gloves was carried out on the dry-film, with water, $1 \%$ ammonia, or $0,01 \%$ of cationic soap as a washing agent. The dry-surgical film leaching appear to be more effective, because both surface complete removal of hydrophilic material is required. 
Figure 6 shows the effect of leaching on the physical properties of surgical gloves. It indicates that the amount of extractable protein content of gloves (before leaching the extractable protein content $2500 \mu \mathrm{g} / \mathrm{g}$ ) can be effective removed, when the surgical gloves is leached in $0,01 \%$ cationic soap solution $(72 \mu \mathrm{g} / \mathrm{g})$. The water soluble protein content (WSP) leached by cationic soap is lower than by water or ammonia, due to the structure of protein which consite of the function groups namely amino and carboxylate group, where the INRL have much corboxylate group than amino group, because the after leaching in with cationic soap the WSP is lesser. From this results it can be recommended that the application of a direct dry surgical gloves leaching is an alternative method to produce lower extractable protein content of the surgical gloves from INRL.

Effect of formulation on allergic response. The study of preparation of 5 formulation (Table 2: A-E) compounds from INRL and HA latex for their allergic responses by ELISA test methods are shown on Figure 7. It can be seen that extremely preparing compound INRL formulation $\mathrm{A}$ is no allergic response in latex hypersensitive Type I. This can be explained that the destructive effect of gamma irradiation, substantially more smearing is observed in ELISA test. Usually the smear is due to the degradation of the higher of molecular weight of proteins, which can cause a reduction Type I allergic response. The increase of absorption of negative response against Type I allergic due to the adding of sodium laurate (Formulation B) sodium laurate + PVA (Formulation C), sodium laurate + CMC (Formulation D) or chemical sulfur for Formulation E. From this results it can be recommended that the application of Formulation A is better than other formulations.

Table 3. The SNI 16-2622-2002/ISO1082-94[27-28] standard quality of surgical gloves and surgical gloves from INRL produced in factory scale (with compound formulation A, Table 2).

\begin{tabular}{|l|c|c|c|c|}
\hline \multirow{2}{*}{ Properties } & \multirow{2}{*}{$\begin{array}{c}\text { Treat } \\
\text { ment }\end{array}$} & \multicolumn{2}{|c|}{ SNI or ISO standard } & Surgical gloves from INRL \\
\cline { 3 - 5 } & Type I & Type II & \\
\hline \multirow{2}{*}{ Tensile strength, MPa. } & $\mathrm{A}$ & $23^{*}$ & $17^{*}$ & 25 \\
\cline { 2 - 5 } & $\mathrm{B}$ & $17^{*}$ & $12^{*}$ & 20 \\
\hline Elongation at break,\%. & $\mathrm{A}$ & $700^{*}$ & $550^{*}$ & 900 \\
\cline { 2 - 5 } & $\mathrm{B}$ & $560^{*}$ & $490^{*}$ & 900 \\
\hline Modulus 500\%, MPa. & $\mathrm{A}$ & $3^{* *}$ & $3^{* *}$ & 2 \\
\hline $\begin{array}{l}\text { Response against Type I allergic } \\
\text { by ELISA test. }\end{array}$ & - & - & - & Negative response \\
\hline A = before aging, B = after aging, * minimum, ** maximum.
\end{tabular}

Quality of surgical gloves. It has been reported that the advantages of rubber product from INRL are: free from nitrosamine, free from chemical accelerators induced allergic, low protein content. Low risk of protein allergic, better clarity, lower ash residue and acid combustion gas, safer 
disposal, less environmental, non copper staining, safe for use in electronic industry, and biodegradable [29-30].

The technical properties of surgical gloves produced in factory scale is shown on Table 3. It indicated that the physical properties of surgical gloves meet either the requirement of ASTM or SNI for natural rubber surgical gloves. The tensile strength and elongation at break of surgical gloves from INRL before and after aging are not only satisfy the SNI or ISO standard, but also more higher. It means that the surgical gloves are more strong and resistance against climate than the standard requirement, while the lower modulus 500\% than the standard means that the surgical from INRL to make it pleasant for user.

In addition, the allergic response as tested clinical latex-sensitive protein allergen by ELISA test is found to be negative (Figure 7). It means that surgical gloves from INRL is safe for user.

\section{CONCLUSION}

The optimum condition for production of surgical gloves from irradiated natural rubber latex (INRL) in factory scale at PT. Laxindo Utama Serang, Banten, Indonesia, has been found.

It is recommended that for producing the lower extractable protein content and negative response against Type I allergy through ELISA test of the surgical gloves from INRL, application of a direct dry surgical gloves leaching in cationic soap is needed.

The physical and mechanical of surgical gloves from INRL compound A such as tensile strength, modulus, and elongation at break are found to meet the requirements of the ISO or SNI standard for surgical gloves. While the allergic response as tested clinical latex-sensitive protein allergen by ELISA test (Figure 7) is found to be negative. It means that surgical gloves from INRL is safe for user.

\section{REFERENCES}

1. LAI P.F., and K.P.Ng. (1995). Education Symposium, ACS, Philadelphia, May 2-5, 1995. 37 pp.

2. RAJAMAL G. Latex Protein Allergy, First Meeting of Working Group on Natural Rubber Protein Allergy, Kuala Lumpur, $2^{\text {nd }}$ July 2004 . (31 pages)

3. GORTON A.D. The Evaluation of New Activator/ Accelerator in Natural Rubber Latex, NR Technology Vol.19 part 11 Publication 1238.(1988)

4. DONALD C. HARVERY and THOMAS FAZIO, Human exposure to nitrosamines from foods, Food Technology, Vol. 39, No. (1) 80-83 
5. WILLOUGHBY B.G. and K.N. SCOTT, Nitrosamines in Rubber, RAPRA Technology Ltd.(1997) 1-87

6. DALRYMPLE S.J., and B.G. AUDLEY, Allergenic protein levels, Rubber Developments, Vol. 45 no.213, NR. Technology 1414 (1992) 51-60

7. LEHRMAN E. Selecting the Right Gloves, htt://www.imune.com/rubber/ nr3.html, Agustus 29 (1996)

8. MORALES C.,A. BASONA J., A.SASTRE, Anaphylaxis produced by rubber globes contact, Cure report and immunologicaql identification of antigens involved, Chemical and Experimental allergy, 19 (19879) 425-30

9. GERSHWIN M.E., Clinical Reviews in Allergy, Vol. 11 No.3 (1993) 293-421

10. TAYLOR J., Y.H.LEOW, Cutaneous reaction on to rubber, Rubber Chemistry and Technology, Vol.73, 3 (2000) 420-453

11. MAKUUCHI K. Progress in RVNRL, Proc. IRC'97, Kuala Lumpur, 6-9 October 1997, RRIM, Kuala Lumpur (1997) 107-116

12. MARGA UTAMA, (1997) The Effective Solution of Dipping NRL problem through Radiation Vulcanization Technique, Bursa Teknologi, Puspitek Serpong, August, 12-14 1997 (6 pages)

13. VERGESE S. Y.KATSUMURA, K.MAKUUCHI, F.YOSHII, production of soluble protein free latex by irradiation process, Rubber Chemistry and Technology, Vol. 73, 1(2000): 80-88

14. SISWANTO, Current Research of NRL Protein Allergy in Indonesia, First Meeting of Working Group on Natural Rubber Protein Allergy, Kuala Lumpur, $2^{\text {nd }}$ July 2004 (19 pp)

15. SUNDARDI F, Review of radiation processing for NRL in Indonesia, Plastics and Rubber Processing and Application, 5 (1985) 119-123

16. RIDWAN M., Pilot scale experiments on RVNRL, Padiation Phys. Chem.Vol 25, 4-6 (1985) 887-892

17. MARGA UTAMA, H.M.HALIK, SISWANTO, YOHARMUS S., HERWINARNI, SUHARYANTO, B.HANDOKO, Trial production of Low Protein INRL in Factory Scale by Gamma Irradiation Technique, The 2003 A Workshop on The Utilization of Research Reactors. JakartaSerpong, January 12-16, (2004) 6 pp

18. MARGA UTAMA, F.YOSHII, T.KUME, K.IKEDA, K.MAKUUCHI, Trial production of Low Protein INRL by Low Energy Electron Beam, The 2003 A Workshop on The Utilization of Research Reactors. JakartaSerpong, January 12-16, 2004.10 pp., Anaphylaxis produced by rubber gloves contact, 
19. MARGA UTAMA, Trial production of condom from INRL on factory scale, Frontiers of Polymers and Advanced materials, Edited by Prasad,P.N., Plenum Press. New York (1994) 627

20. MARGA UTAMA, Trial production of examination gloves from INRL on factory scale, Edited by Prasad,P.N., Plenum Press. New York. (1994) 649

21. ASTM., Standard specification for latex concentrated, ammonia preserved, creamed, and centrifuging natural latex, ASTM D (2005) 1076-95

22. ASTM., Standard test method for tension, ASTM (2005).D 412-87

23. ASTM., Standard test method for analysis of protein in natural rubber and its product, ASTM (2005) D 5712-95

24. SISWANTO, SUHARYANTO, D. SANTOSO, A. DARUSAMIN, Research progres on allergic protein of Hevea brasiliensis in Indonesia, Proc. Indonesian Rubber Conference and IRRDB Symposium 2000, IRRI, Bogor (2001) 409-419

25. NG, K.P.E. and YIP and K.L.MOK,. Production of NRL gloves with low extractable protein content: some practical recommendation, J. Natural. Rubber. Res., 9, 2 (1994) 87-96

26. SUKRI BIN HJ.AB.WAHAB, K.MAKUUCHI, R.DEVENDRA, and C.P.PANSA, S. Effect of heating and leaching on mechanical properties of RVNRL film., Proc. International Symposium on RVNRL, edited by S.Machi, JAERI-M, 89-228, Tokyo (1990) 216-225

27. SNI. (2002) Sarung tangan karet steril sekali pakai untuk keperluan bedah, BSN, SNI 16-2622-(2002)

28. ISO.(1994). Single-use sterile surgical rubber gloves (specification), ISO 10282-(1994)

29. MAKUUCHI K., An Introduction to Radiation Vulcanization of Natural Rubber Latex, T.R.I. Global Co., Ltd., Bangkok (2003)

30. WAN MANSHOL BIN ZEIN, RVNRL, pilot Scale preparation, cost and application, Proc. IRC'97, Kuala Lumpur, 6-9 October 1997, RRIM, Kuala Lumpur. (1997) 117-126 